\title{
Cuestión de tiempo: Michael Fried y el tiempo del arte moderno
}

\section{A matter of time: Michael Fried and the time of modernist art}

\author{
David Díaz Soto \\ Universidad Complutense, Departamento Filosofía IV \\ daviddesoto@hotmail.com
}

Resumen • En el siglo XIX, autores fundacionales del formalismo, como Fiedler o Hildebrand, contrapusieron estrictamente las artes plásticas, "puramente visuales», a las artes verbales del discurso, proscribiéndoles la narración y disociándolas de la temporalidad: se trata del "principio de exclusión del tiempo», vinculado al formalismo. Más tarde, el crítico «modernista» de arte Clement Greenberg planteó la instantaneidad, en tanto que opuesta a la duración, como modalidad ideal de la experiencia artística. Pero el historiador y crítico de arte Michael Fried, en sus textos de los años 60 sobre arte abstracto, se distancia de Greenberg, desarrollando un discurso sobre la temporalidad en las artes plásticas, con nociones como "tiempo visual»; y en sus posteriores textos historiográficos investiga las modalidades temporales de la representación pictórica. La aparente paradoja entre la crítica de Fried a la hipóstasis «literalista» de la duración en las tardovanguardias y el papel crucial que concede a Manet y a la instantaneidad en el origen del arte moderno, la resolveremos atendiendo a su reivindicación de la temporalidad durativa de "lo cotidiano». Así cabe comprender la concepción de la modalidad temporal característica de la modernidad y del arte moderno, a la que apunta su noción teórica de presentness.

Palabras clave: formalismo, pintura moderna, pura visualidad, instantaneidad, duración.

Abstract - In the nineteenth century, seminal authors of Formalism, like Fiedler or Hildebrand, strictly compared the "purely visual» plastic arts to the discursive arts of verbal language, ruling out narrativity from plastic arts, which they dissociated from temporality - the formalist "principle of exclusion of time». Later on, «modernist» art critic Clement Greenberg claimed that instantaneousness, as opposed to duration, was the ideal modality for artistic experience. Art critic and historian Michael Fried did not share Greenberg's position, but developed instead a discourse about time in plastic arts. In his early critical writings on abstract art of the 60's, he deploys such notions as «visual time», while his later art-historical writings explore temporal modalities in pictorial representation. The apparent paradox between the key role Fried attributes to Manet and instantaneousness in the origins of modern art, and Fried's own critique of the «literalist» hypostasis of duration in late avant-garde art, can be solved in the light of Fried's vindication of the durative time of «the everyday». This allows us to understand the characteristic time modality of modern art and of the modern era, pointed in Fried's notion of presentness.

keywords: Formalism, modernist painting, pure visuality, instantaneousness, duration. 
En las recientes discusiones en torno al formalismo como teoría de las artes plásticas, suele vincularse a la posición formalista cierto "principio de exclusión del tiempo", cuyos antecedentes teóricos se remontarían hasta Lessing (aunque él no era propiamente un «formalista»). Es bien conocida la contraposición entre «artes del espacio» y «artes del tiempo", que formuló Lessing en su Laokoon, oder über die Grenzen der Malerei und Poesie, de 1766:

Mi razonamiento es el siguiente: si es cierto que la pintura, para imitar la realidad, se sirve de medios o signos completamente distintos de aquellos de los que se sirve la poesía -a saber, aquélla, de figuras y colores distribuidos en el espacio; ésta, de sonidos articulados que van sucediéndose a lo largo del tiempo-; si está fuera de toda duda que todo signo tiene necesariamente una relación sencilla y no distorsionada con aquello que significa, entonces signos yuxtapuestos no pueden expresar más que objetos yuxtapuestos, o partes yuxtapuestas de tales objetos, mientras que signos sucesivos no pueden expresar más que objetos sucesivos, o partes sucesivas de estos objetos.

Los objetos yuxtapuestos, o las partes yuxtapuestas de ellos, son lo que nosotros llamamos cuerpos. En consecuencia, los cuerpos, y sus propiedades visibles, constituyen el objeto propio de la pintura. Los objetos sucesivos, o sus partes sucesivas, se llaman, en general, acciones. En consecuencia, las acciones son el objeto propio de la poesía (106-107).

Según el autor, pues, las artes «del tiempo», entre las que se contarían las literarias, emplean «signos sucesivos", en principio palabras, que se despliegan y son escuchadas (y eventualmente, también leídas) sucesivamente, a lo largo del tiempo. En cambio, las "artes del espacio», fundamentalmente las plásticas, emplearían «signos yuxtapuestos», que se despliegan y son vistos simultáneamente en el espacio. Por ello, concluye, las artes literarias serían más aptas que la pintura para narrar la acción; la pintura, en cambio, sólo podría narrar indirectamente, "por alusión".

Ahora bien, en el formalismo, el "principio de exclusión del tiempo» se construye a partir de una noción que Lessing no empleó en su Laokoon: la de una multiplicidad de «esferas sensoriales», que son especialmente dos: lo visible y lo audible. Dicha noción provenía de hallazgos científicos sobre la diversidad de los canales sensoriales del cuerpo humano y sobre sus energías nerviosas específicas, realizados por fisiólogos de la percepción de mediados del siglo XIX, como Müller (Handbuch der Physiologie) o Helmholtz (Die Lehre von den Tonempfindungen; Handbuch der physiologischen Optik), coetáneos de los primeros teóricos del arte propiamente formalistas ${ }^{1}$. Siguiendo sus sugerencias, los primeros autores formalistas tendieron a postular la separación entre las diversas esferas sensoriales —un afán analítico por distinguir y separar muy característico del formalismo- y a vincular cada una de las artes exclusivamente con una, y sólo una, de ellas, como ámbito operativo al cual debían atenerse los respectivos recursos legítimos de dichas artes (Fiedler, Escritos, 202-211; Hanslick, Vom Musikalisch-Schönen, 20-21). Ello implicó, a su vez, un principio de separación entre las artes: por un lado, las plásticas, que serían "puramente visuales», por otro, la música, que sería "puramente sonora", etc., y, finalmente, las literarias, a las que resultaba problemático asignarles una «esfera» determinada, como no fuera la de «lo verbal», que difícilmente puede considerarse una esfera «sensorial».

Sobre dichos hallazgos científicos, su influencia sobre la teoría del arte y sus vínculos con los orígenes de la subjetividad moderna y de la llamada «sociedad del espectáculo», remitimos al lector a la crucial monografía de Jonathan Crary. 
Durante la segunda mitad del siglo XIX, teóricos formalistas de las artes plásticas, como Konrad Fiedler o Adolf Hildebrand, concibieron la pintura y la escultura en términos de "pura visualidad» (Fiedler, Escritos, 209-220), y en fuerte contraposición con las artes «del tiempo", sobre todo las literarias. Éstas poseen recursos narrativos, de representación del curso de la acción en el tiempo, que parecen ilegítimos para las artes plásticas $^{2}$. Quedó así proscrito de las «artes visuales» todo cuanto tuviese que ver con lo sucesivo, con el tiempo; pues a lo visual «puro» le sería consustancial la espacialidad, pero el tiempo le sería extrínseco: una aserción que quizá podría buscar fundamento ontoepistemológico en las tesis de Kant, en la «Estética Trascendental» de la Crítica de la Razón pura, sobre espacio y tiempo como «formas puras a priori» fundamentales de todo el ámbito fenoménico ${ }^{3}$. Por tanto, para un teórico formalista sería improcedente cualquier consideración de "cuestiones de tiempo» (y en particular, del tiempo como «duración») en el análisis de obras de las artes plásticas, dado que ellas son "puramente visuales». Así, todas las modificaciones que sufre producto de la duración temporal serían accidentales a la estructura formal propiamente dicha de la obra: meras contingencias, que le acontecen en tanto que no deja de ser un objeto material y, por tanto, comparte con el resto de los objetos materiales muchas propiedades que no la caracterizan como obra de arte; entre ellas, la de tener una existencia física que «dura» en el tiempo y que puede verse alterada por la acción del entorno variable.

Ahora bien, dentro del marco conceptual del formalismo, la cuestión se complica con las nociones vinculadas de lo «háptico» y de la "visión cercana», que quedarían incorporadas como «lo táctil» al sistema de categorías formalistas para el análisis plástico de las obras artísticas, sintetizado por Heinrich Wölfflin (26-29). La complicación se manifiesta en el siguiente pasaje de Hildebrand:

Si el espectador se acerca más, teniendo que acomodar la vista para ver el objeto dado, cesa por un momento la totalidad de la apariencia y sólo puede componer una imagen de naturaleza temporal, por medio de movimientos oculares, y a modo de diferentes acomodaciones. Se divide, pues, la totalidad de la apariencia en diferentes impresiones ópticas que se aúnan mediante el movimiento ocular.

Cuanto más se aproxima el espectador al objeto, más movimientos oculares necesita y tanto más reducidas son las impresiones ópticas homogéneas. Por último, si se es capaz de delimitar la impresión visual de tal modo que siempre coloque sólo un punto definido en el foco visual, y de experimentar la relación espacial de esos diversos puntos a modo de

Esto requeriría matizaciones. Como señala Pérez Carreño (Fiedler, Escritos, 31), sobre las artes de la palabra, Fiedler se limita a decir que, en la medida en que son tales, en ellas «la palabra está al servicio de la intuición, no del concepto» (Fiedler, Schriften, vol. 2, 297, 397). Pero Fiedler (Escritos, 178-182) sí que contrapone fuertemente el conocimiento conceptual y discursivo — ligado al lenguaje verbal, en sus usos ordinario y científico - al peculiar modo de conocimiento que ofrecería el arte plástico, exclusivamente basado en representaciones visuales; téngase en cuenta el nexo entre lo discursivo y lo temporal, en tanto que durativo. Por su parte, Hildebrand, insiste también Pérez Carreño, no ignora la capacidad de la escultura para representar, mediante la «forma activa», formas orgánicas en movimiento y acción, es decir, «valores funcionales» (Hildebrand, 79-87). Pero no parece proclive a alabar las virtudes de una plástica propiamente narrativa, ni en su principal escrito teórico, ni en su propia obra como escultor. Y para Wölfflin, paradójicamente, el pictoricismo «puramente óptico» sería ideal para representar plásticamente el movimiento (266).

3 Si bien la «kantianidad» de semejante análisis es discutible, dado que la forma pura a priori del tiempo, en Kant, posee un carácter especialmente fundamental con respecto a la conciencia y a lo fenoménico, lo cual hace problemático el considerar a ambas formas puras, espacio y tiempo, de modo equiparable y por separado, como lo exigiría la plena justificación del postulado formalista de «exclusión del tiempo». 
un acto de movimiento, entonces la vista se transforma verdaderamente en tacto y en un acto de movimiento, y las representaciones que se apoyan en él ya no son representaciones ópticas, sino representaciones de movimiento, y constituyen el material de la visión y representación abstractas de la forma (25-26).

Admitir algo semejante como uno de los dos modos alternativos e igualmente viables de la visualidad permite reconocer la capacidad de las artes plásticas para representar rasgos como el volumen y la textura de superficie de objetos sólidos, que corresponderían a la esfera sensorial del tacto, a pesar de haber caracterizado a dichas artes como "puramente visuales» ${ }^{4}$. Pero semejante modalidad visual, según la conciben estos teóricos formalistas, supone «transformar la percepción en algo temporal» (Hildebrand, 26): vinculada a movimiento y duración, implica un carácter secuencial de la visión, una sucesión de múltiples perspectivas parciales sobre un objeto, que luego la representación plástica "puramente visual» ha de sintetizar en una imagen unificada y sinópticamente accesible a la mirada, cancelando así la sucesividad y la multiplicidad. Por ello mismo, la categoría de lo táctil tuvo siempre un estatuto problemático en el formalismo 5 .

Parecería que la obra de arte plástica, conforme a la concepción formalista, o bien ha de pensarse en términos estrictos de "atemporalidad», o bien, de existir algún modo de temporalidad particularmente coherente con su naturaleza, sólo podría ser el de lo instantáneo, puesto que parece el más alejado del carácter durativo del tiempo, del cual vendría a ser como lo opuesto ${ }^{6}$. Ya a mediados del siglo XX, el crítico norteamericano Clement Greenberg, en un célebre pasaje, plantea explícitamente la instantaneidad como ideal normativo para la pintura:

[...] el arte pictórico en su definición más elevada es estático; trata de superar el movimiento en espacio o tiempo. [...] idealmente, la totalidad de un cuadro debería ser accesible de un vistazo; su unidad debería ser inmediatamente evidente [...] Y esto es algo que ha de ser captado sólo en un instante indivisible de tiempo. Nada de expectación queda involucrado en la experiencia pertinente y verdadera de un cuadro; una pintura, lo repito, no «va surgiendo» del modo como lo hacen una historia, o un poema, o una pieza musical. Está toda ahí, como una revelación repentina (80-81).

Ello se integra en una formulación tardía, «greenberguiana», del llamado «Modernismo", peculiar posición histórico-crítica que aplica conceptos procedentes del formalismo con el fin de legitimar cierta línea privilegiada de arte moderno.

Michael Fried es un heterodoxo historiador y crítico de arte norteamericano, a quien, atendiendo a su vínculo personal e histórico con Clement Greenberg, se le han imputado

$4 \quad$ Y ello, en la misma medida en que estos teóricos formalistas fundacionales, empezando por Fiedler (Escritos, 221-225), desdeñaron la idea de que la esfera sensorial del tacto pudiese fundar un «arte puramente táctil», capaz de organizar sus materiales perceptuales en una representación formulada en términos táctiles «puros» (tal como harían las artes "puramente visuales» en su esfera sensorial) y que pudiese incluirse en el «Sistema de las Artes», establecido desde el siglo XVIII. Una opción sería considerar que la escultura es ese arte "puramente táctil», pero para los formalistas correspondía, igual que la pintura, a la esfera de la visualidad.

5 Así, Wölfflin, al considerar el «cambio capital» de toda la historia del arte — hacia el «pictoricismo»—, presenta la «imagen visual» (Sehbild), frente a la «táctil» (Tastbild), como el producto de «un arte más evolucionado, que ha aprendido a confiar en el puro fenómeno", en lugar de pretender corroborarlo siempre con las constataciones del tacto (36).

6 Obviamente, no es lo mismo la instantaneidad que la intemporalidad o atemporalidad; pero, desde la perspectiva formalista, tendieron a hacerse equivalentes. 
posiciones formalistas, entre ellas, la adhesión al "principio de exclusión del tiempo». Sin embargo, las cosas no son tan simples, pues Fried, polemizando contra el formalismo, ha concedido un importante papel al tiempo - y especialmente, al tiempo en tanto que duración - como aspecto relevante para las artes plásticas, sobre todo la pintura. Ello se ha manifestado en las dos etapas principales de la actividad de Fried: primero, como crítico de arte interesado en la producción artística de su propia época; y más tarde, como historiador del arte comprometido en una singular reconstrucción de los orígenes del arte moderno.

Ya durante la década de 1960, en textos de su etapa como crítico de arte abstracto ${ }^{7}$ Fried parece ensayar un compromiso entre su posición personal, sensible a las implicaciones del tiempo en las artes plásticas, y el discurso más estrictamente formalista-purovisualista de Greenberg, a quien admiraba por su gran altura como crítico (quizá más que como teórico, pues en eso tenía sus reservas).

En varios textos de a partir de finales de la década de 1950, Greenberg (68-61, 90, 96-98) había propuesto la noción de un «espacio puramente óptico» (que excluiría, por cierto, toda asociación de cualidades táctiles), un espacio penetrable a la visión sólo en la experiencia imaginativa de la obra de arte pictórica, y contrapuesto al espacio físico, real, donde se despliega la acción humana en el tiempo. A la vez, Fried, en sus análisis de obras pictóricas de Jules Olitski o Morris Louis, introduce la noción de un «tiempo óptico", que discurriría únicamente en la experiencia visual imaginativa de la obra. Según sostiene en su célebre «Three American painters», de 1965, los cuadros abstractos de Olitski de aquella época ofrecerían una experiencia de "secuencialidad cromática» ${ }^{8}, 0$ percepción sucesiva e individualizada, más que simultánea y coordinada, de los diversos campos cromáticos, poniendo así a prueba la consistencia de cualquier posible combinación de colores:

Cualesquiera colores pueden combinarse, si se puede hacer que el espectador los vea de uno en uno, secuencialmente en el tiempo, y no todos de una vez, como en una forma o diseño percibido instantáneamente. Y ver los colores singulares secuencialmente podría obligar al espectador a una confrontación más intensa con cada uno de ellos sucesivamente de lo que sería posible lograr, ya sea relacionando los mismos colores unos con otros en un diseño que, por así decir, no tenga dimensión temporal, o bien aislando cada uno de los elementos singulares de color en un lienzo propio, vacío de toda otra cosa. Sería infructuoso especular con la cuestión de si estas ambiciones coloristas son realizables sólo si se hace jugar un papel crucial a la duración en la experiencia de una obra de arte; lo importante es que la mayoría de los cuadros de Olitski ejecutados desde 1963 que he visto [Fried escribe esto en 1965] exigen virtualmente ser experimentados en lo que tal vez pueda llamarse tiempo visual (Fried, Art and objecthood, 247).

Buena parte de esos escritos — aunque no todos-quedarían recogidos, décadas después, en su antología de textos críticos (Fried, Art and Objecthood), por cuya paginación los citamos cuando es el caso. Excepto indicación contraria, las traducciones de Fried y Greenberg son nuestras.

8 En su temprana «New York Letter» de noviembre de 1962, Fried ya analiza en esos términos la obra Equator, de Louis (Art and objecthood, 282). Más tarde, en "Jules Olitski», de 1967, hablará de un flujo cromático direccionalmente orientado (Art and objecthood, 135, 140); y en «Recent work by Kenneth Noland», señala la «vectorialidad» y «velocidad» de las bandas horizontales en los cuadros de Noland posteriores a 1967 (Art and objecthood, 186). La noción de una percepción secuencial del color reaparecerá en la obra historiográfica de Fried, al menos una vez, en el análisis de Théâtre du Gymnase (1856, Berlín, Nationalgalerie), un óleo del pintor «realista» decimonónico Adolf Menzel (Menzel's realism, 98). En «Three American painters», Fried (Art and objecthood, 246, 247) sostenía que la experiencia secuencial del color se encuentra ya en artistas flamencos del Renacimiento y el Barroco, de Van Eyck a Vermeer. 
Esa «temporalidad puramente visual» permitiría comparar las obras de artistas como Olitski con «la música, el arte del tiempo par excellence» (Fried, Art and objecthood, 247, cursivas en el original). Pero, según Fried, a diferencia de lo que ocurre en caso de la música (donde siempre habría una relación entre duración real de la ejecución de la obra y temporalidad vivida de su escucha), aquí se trataría de un tiempo puramente fenomenológico, enteramente diverso de la duración real del acto de contemplación de la obra, del mismo modo que el «espacio óptico» del que hablaba Greenberg sería inconmensurable con el espacio físico tridimensional de la realidad.

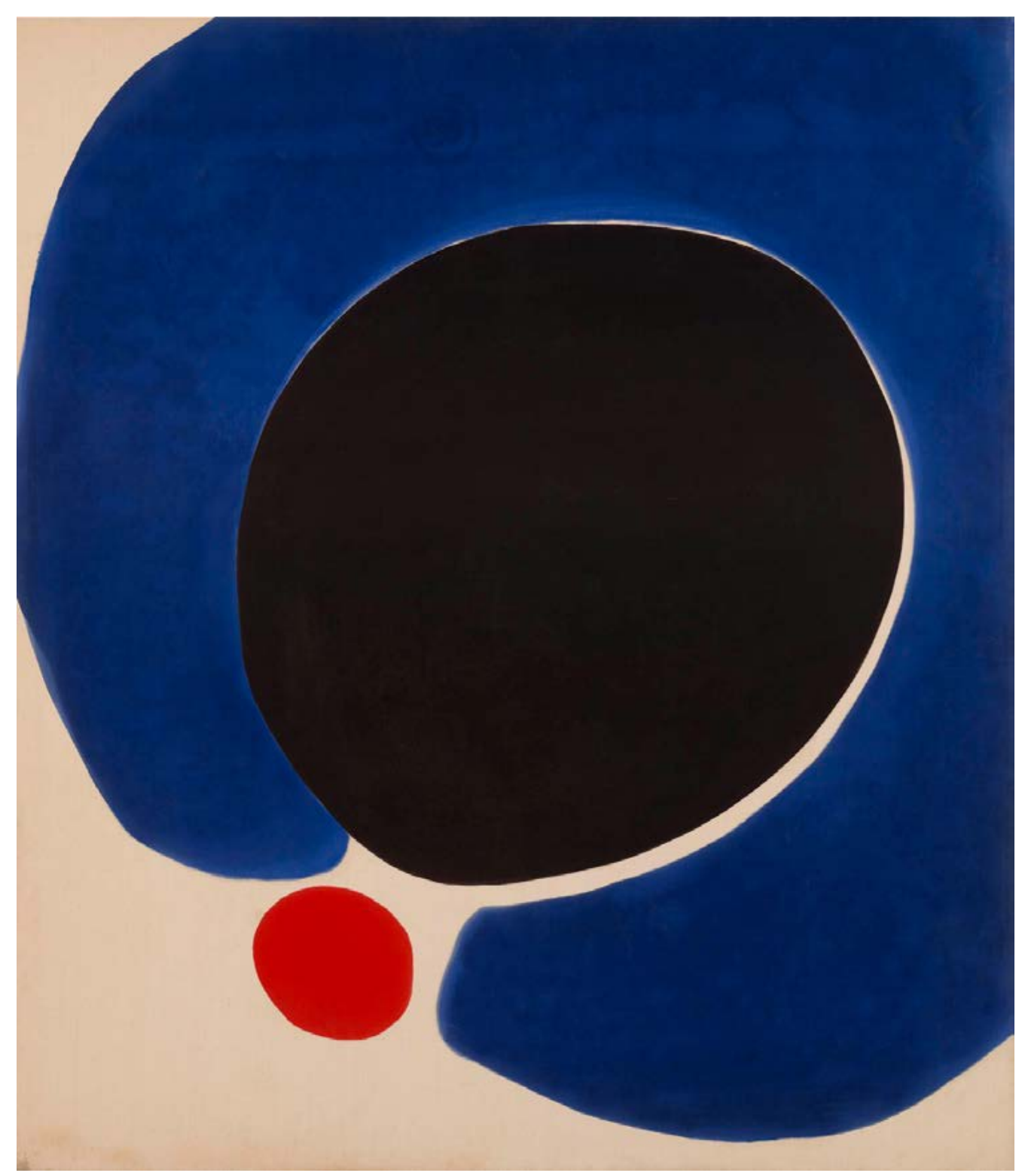

Cleopatra Flesh, Jules Olitski (1962) 
Asimismo, Fried recurre en algunos análisis a una «narrativa de autopóiesis», ficcional y diacrónica, describiendo una suerte de proceso autopoiético «impersonal», o «automático", en el que la obra se produciría por impulso propio, ante los ojos del propio espectador, en el desarrollo del acto de su percepción: «Es como si estos cuadros se hicieran a sí mismos ante nuestra vista. [...] No sabemos, ni se nos hace sentir, cómo Olitski aplicó el pigmento al lienzo, y no hay indicaciones táctiles o cinestésicas que nos inviten a participar vicariamente en el propio acto de pintar»; y más adelante: «cuando los cuadros son vistos en lo que he llamado tiempo visual, los elementos individuales de color parecen asumir sus contornos más o menos gradualmente ante nuestros ojos, respondiendo a las fuerzas operantes en la situación cromática total [...]» (Art and objecthood, 248, 250)9 . Con ello, por un lado, interpreta la obra como representación de las condiciones de su propia génesis, enfoque que más tarde aplicará a obras de Caravaggio, Eakins, Courbet o Manet, pero ya sin disociarlo del «acto de pintar» el cuadro por parte del $\operatorname{artista}^{10} ; \mathrm{y}$ también de ese modo, por otro lado, comparte la aversión de muchos teóricos formalistas hacia los excesos sentimentales y subjetivistas, asumiendo el mismo ideal cuasi normativo de «objetividad» y de supresión de la individualidad del artista al que tendieron muchos autores formalistas ${ }^{11}$ (aunque Fried vincula ese ideal más bien al «simbolismo»): «[...] el arte de Louis puede sorprender por ser extraordinariamente impersonal [...] De hecho, los cuadros de Louis, más que los de ningún otro pintor anterior, dan la sensación de haber llegado a la existencia como por iniciativa propia, sin intervención del artista» $(\text { Art and objecthood }, 126)^{12}$. Pero al introducir lo diacrónico, Fried subvierte la terminología greenberguiana y el presupuesto formalista de exclusión del tiempo y la duración de las artes «visuales».

Su posición, pues, es clara desde el principio: la relación entre artes plásticas y temporalidad no es de ningún modo extrínseca. En consecuencia, ha abordado más tarde, ya

9 Estas ideas las proponía ya Fried en un temprano texto sobre Louis (Fried, «Some note on Morris Louis», 25-26), vinculando la noción greenberguiana de «espacio óptico» a la impersonalidad en la creación y a la autopóiesis de la obra, junto a la noción de una lógica causal y temporal exclusivamente artística, distinta de la que gobierna la realidad extra-artística. Sostiene Fried (Art and objecthood, 317-318) que obras de Olitski como Beautiful bad woman o Fatal plunge lady (ambas de 1963) aparecen como resultado del despliegue de «fuerzas cromáticas» en el «tiempo visual». Todavía en su primera gran monografía como historiador del arte (Absorption and thetatricality, 81-82), analiza la «dramaturgia de autopóiesis» de las composiciones del género «menor» del bodegón en el arte «antiteatral» francés del siglo XVIII, en analogía con el género "mayor» del "cuadro de historia», narrativo y con tema mitológico, religioso o propiamente histórico.

10 A las obras cuya principal interpretación considere que es de ese tipo, Fried las denominará «alegorías reales», parafraseando el título del célebre óleo El taller del pintor, de Courbet (1855, París, Musée d'Orsay), también conocido como Alegoría real.

11 Recordemos la provocativa propuesta antibiográfica de una «historia del arte sin nombres», atribuida, desde comienzos del siglo XX, a Wölfflin (13-26), admirador y discípulo de Hildebrand.

12 Esas tesis se relacionan con el rechazo que Greenberg y también Fried (durante su primera etapa como crítico) manifestaban hacia el dibujo, concebido como mera delineación a mano alzada de contornos de figuras, por su supuesta «arbitrariedad» y sus «asociaciones táctiles» (recordemos que Wölfflin vinculó lo táctil y lo lineal, contrapuestos a lo óptico y lo pictoricista); si bien el rechazo de Fried hacia lo táctil, a diferencia del de Greenberg, no es categórico, sino circunscrito a una coyuntura histórica concreta. Ello enlaza con la problemática de la «justificación» de la organización o estructura pictórica: según Fried, éste sería el problema principal para los grandes artistas de esa época, y su más desarrollada solución sería la llamada «estructura deductiva» de las obras de Frank Stella o Kenneth Noland. La alternativa a esa solución sería el efecto «autopoiético» —es decir, impersonal, y por ello, no «arbitrario»— de despliegue en un «tiempo visual», que lograrían las obras «no-deductivas» de Olitski, mediante la técnica de «empapado" del soporte con pigmento diluido. Nos remitimos a las secciones 3.4.2. y 3.4.3. de nuestra tesis doctoral sobre Fried (Díaz Soto, Michael Fried y el debate sobre el formalismo norteamericano). 
como historiador del arte, diversos aspectos de la relación entre temporalidad y pintura: uno de ellos es la temporalidad propia del acto pictórico de creación; otro es la temporalidad experimentada en el acto de recepción de la obra, impuesta a éste por la representación que es en él interpretada; asimismo, hay una temporalidad literal de la duración real del acto o situación de contemplación-exhibición, cuya hipóstasis Fried reprocha al arte minimal. Y en particular, ha desarrollado un discurso sobre la representación (o si se quiere, la «ilusión») de distintas modalidades temporales en pintura.

En su Courbet's Realism, Fried habla de «efectos de duración» en la experiencia de obras pictóricas, que estarían ligados a efectos de alteración y diferimiento hermenéutico entre el contenido representativo explícito de la obra y su significado profundo: «[En el arte de Courbet], los efectos de duración están asociados, y de hecho, son indiscernibles, de efectos de lectura, que implican la transformación radical de aquello que, de un modo aparentemente evidente, está ahí para ser visto» (180, cursivas en el original). Tales efectos serían producto de actos interpretativos, que Fried concibe como actos de «lectura» - recordemos el vínculo entre lo sucesivo, lo verbal y lo discursivo- que el espectador, y también el historiador que analiza el cuadro, ejercen sobre los contenidos figurativos de la representación, así como de la resistencia a dichos actos por parte de la obra interpre$\operatorname{tada}^{13}$. Asimismo, el autor desarrolla en su historiografía, desde la década de 1970, un discurso sobre modos de temporalidad en la representación pictórica figurativa, modos que serían independientes de la «temporalidad literal», es decir, de la duración real del acto de contemplación o la situación de exhibición de la obra.

Fried describe dos modalidades extremas de temporalidad en la representación pictórica (Manet's Modernism, 290-292; Realism, Writing, Disfiguration, 42-44), que tendrían fundamento ontológico en distintas propiedades del medio y soporte pictóricos y que estarían vinculadas a ciertas temáticas u objetos de representación característicos de cada una de ellas. La modalidad «durativa» se basaría en que un cuadro, como objeto sólido, material y autoidéntico, tiene una existencia con duración literal en el tiempo, subsistiendo relativamente sin cambios. A esa modalidad durativa estaría vinculada la ilusión de duración y de solidez de los objetos representados y la profundidad tridimensional del espacio ilusionista en el que aparecen ubicados, suscitando una experiencia de penetración o exploración gradual de dicho espacio ${ }^{14}$. La modalidad «instantánea», opuesta a la anterior, se basaría en el carácter delimitado de la superficie del soporte pictórico, y por tanto, del espacio de la representación. Por tal motivo, según Fried el espacio de la representación pictórica está enteramente orientado hacia el espectador, abriéndose a él en cada uno de sus puntos (rasgo que denomina facingness), y puede, en principio, ser captado en su totalidad en un instante; o al menos, la obra de arte pictórica dispone de recursos para convencer al espectador de que así sucede, pues en definitiva, «Es irre-

13 Esos actos interpretativos franquean el acceso a lo que Fried llama «estructuras de expectación» (structures of beholding) del cuadro: redes cuasi narrativas, producto de asociaciones de identificación y oposición entre el espectador del cuadro (también, eventualmente, el «espectador primordial» que es el propio autor de la obra) y los diversos contenidos figurativos del mismo. La metodología fundamental de Fried, sobre todo en su monografía sobre Courbet (pero también en sus estudios sobre Eakins, Manet, Caillebotte, etc.) es, pues, de carácter analógico y hermenéutico, y suele consistir en un análisis de tales «estructuras».

14 Fried asocia lo durativo, lo táctil y lo proximal a lo "corpóreo», y a los lentos procesos vegetativos inconscientes («automáticos») que fundamentan la vida orgánica: parte de la clásica dualidad «óptico/táctil» (con su correlativa, «instantáneo/durativo») del formalismo, pero invierte sus prioridades, interesándose especialmente por todo lo que él considera ligado a lo «táctil». 
levante si el ojo humano puede realmente hacer eso o no, lo que importa es la convicción por parte del espectador de que puede hacerlo y lo hace» (Manet's modernism, 291). La facingness es un aspecto importante del concepto de presentness del medio pictórico que Fried maneja, sobre el cual volveremos.

En cuanto al tema, o contenidos representativos, al modo durativo le correspondería representar cosas «esencialmente inalterables». Entre tales cosas, estarían la naturaleza muerta y cierto tipo de paisajes ${ }^{15}$, o bien lo que Fried denomina temas "absortivos» ${ }^{16}$ : uno o unos pocos personajes, ensimismados en cierto tipo de actividades nimias, de carácter reiterativo y que exigen cierto despliegue en el tiempo, con implicaciones, además, de lentitud ${ }^{17}$. Igualmente se contarían entre esos temas "absortivos» las representaciones de personajes en estado de adormecimiento. El efecto de las escenas absortivas es de duración, pues en ellas sólo se representa un instante de una acción que, sin embargo, no tiene ningún momento de su despliegue que resulte particularmente destacable, de modo que el instante representado remite a todos los demás y parece extenderse a todos ellos. Fried afirma que la modalidad «absortiva» está históricamente vinculada al «realismo» pictórico:

[...] en la pintura occidental, al menos desde el siglo XVII, la temática absortiva ha constituido a menudo la matriz representacional del realismo pictórico. Esto se debe a varias razones, de las cuales no es la menos importante la concordancia subyacente entre la temporalidad implícita de la representación y la temporalidad real (o «material») del propio cuadro - lo que equivale a decir que el realismo pictórico en Occidente frecuentemente ha implicado una ilusión tácita, o implícita, del paso del tiempo, de pura duración, tan plenamente como otra ilusión, más evidente, de solidez de los objetos (Manet’s modernism, 291).

Es notorio que el autor entiende de una muy peculiar manera la noción de «realismo pictórico», aquí ligada a la de lo «absortivo». Artistas como Chardin, Millet, Courbet o Thomas Eakins habrían destacado en esa modalidad.

15 En particular, aquellos paisajes representados conforme a la "poética pastoral», la cual, según Fried, habría regido este género en época de Diderot (Absorption and theatricality, 118-132).

16 De hecho, lo durativo sería rasgo dominante de toda la pintura occidental de carácter «absortivo", y Fried sostiene que «esos términos caracterizan la modalidad temporal de toda pintura esencialmente absortiva en la tradición occidental, desde Caravaggio y Rembrandt, pasando por Chardin, Millet, Courbet e Eakins» (Courbet's realism, 179-80, cfr. también 108).

17 Fried habla de «efectos de duración, de acciones lentas o repetitivas o continuas» (Courbet's realism, 179). 


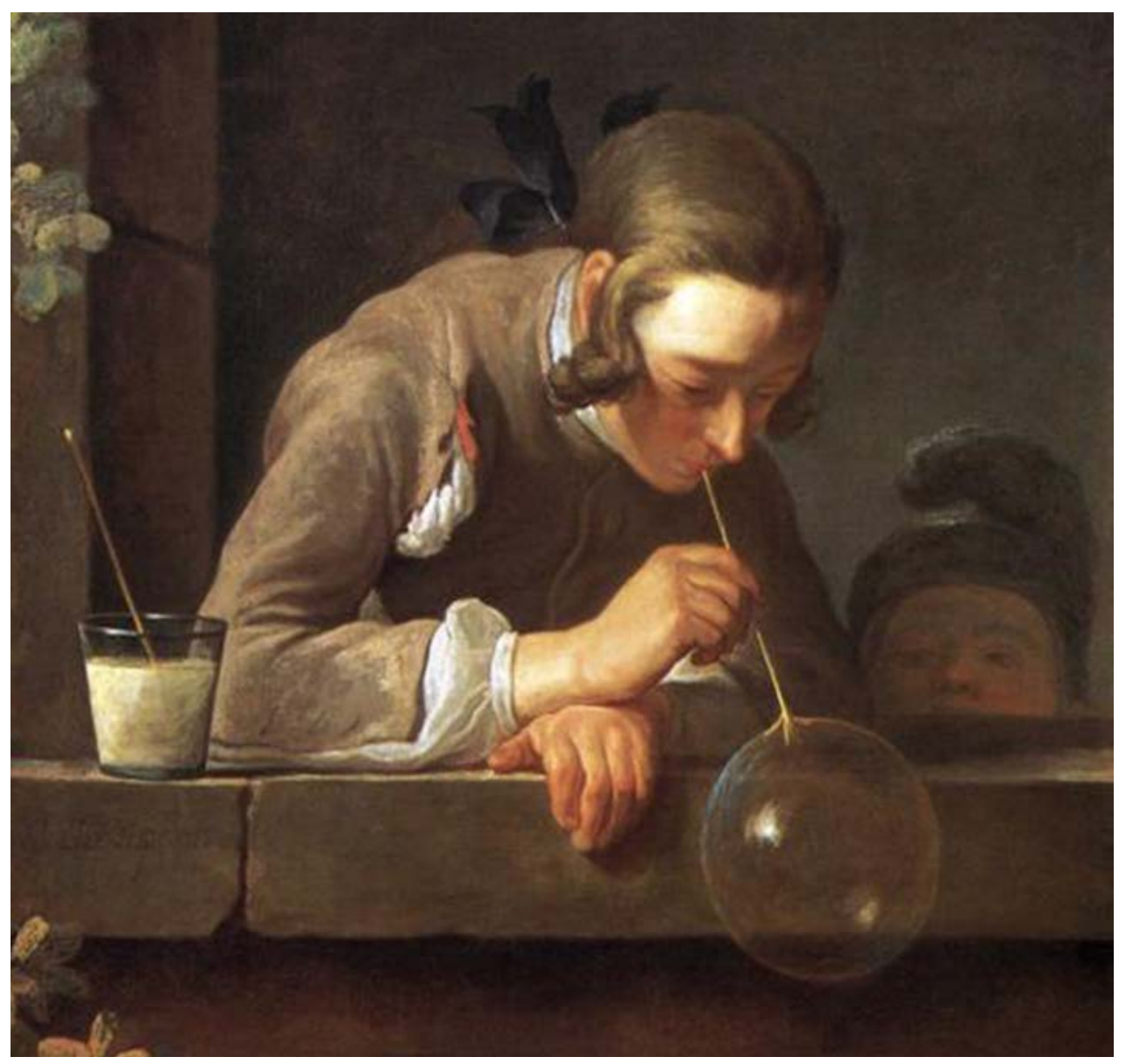

Soap Bubbles, Jean-Baptiste-Siméon Chardin (1739)

A la modalidad temporal instantánea, en cambio, le corresponderían temas dramáticos. En ellos, el evento o acción representado no es repetitivo y tendrá un curso más diferenciado y jerarquizado; implicará a varios personajes, cuyos gestos, actitudes y posiciones cambian rápidamente a lo largo de su desarrollo, de modo que el instante representado no podrá aludir a todos los demás instantes por simple "reiteración», sino que dará la sensación de ser un único instante concreto. Jacques-Louis David y algunos de sus coetáneos de la época heroica y revolucionaria del arte francés habrían destacado en esa modalidad «dramática». Sin embargo, la representación pictórica dramática, como Fried señala mediante un representativo ejemplo, nunca puede ser puramente instantánea:

[...] la pintura de David [El juramento de los Horacios, 1784, Museo del Louvre, París] parece aprehender un solo momento «pregnante» en el marco de una narración de ritmo rápido. (Se notará, sin embargo, que prestar juramento es en general un acto que exige, cuando menos, una cierta ocupación en el tiempo, y que este hecho ha permitido a David asociar los efectos de la instantaneidad a los de la duración, de modo que ese preciso acto le ha permitido representar el compromiso de los tres hermanos de manera no solamente simultánea, sino sincrónica: como si el espectador tuviera la impresión de que cada uno de ellos estaba exactamente en la misma fase de la acción) («David et l'Antithéâtralité», 211). 
Dado que toda acción requiere un mínimo de duración, la representación pictórica dramática emplea el criterio del «momento pregnante», que formuló Lessing, pero que Fried rastrea también en varios teóricos «antiteatrales» fundacionales (Absorption and theatricality, 76-92): seleccionar aquel instante perspicuo dentro del curso de acción que sea más significativo emotivamente e inteligible dramáticamente que todos los demás, ofreciendo una sinopsis completa de la acción, al sugerir todas las fases de su desarrollo que no se representan ${ }^{18}$.

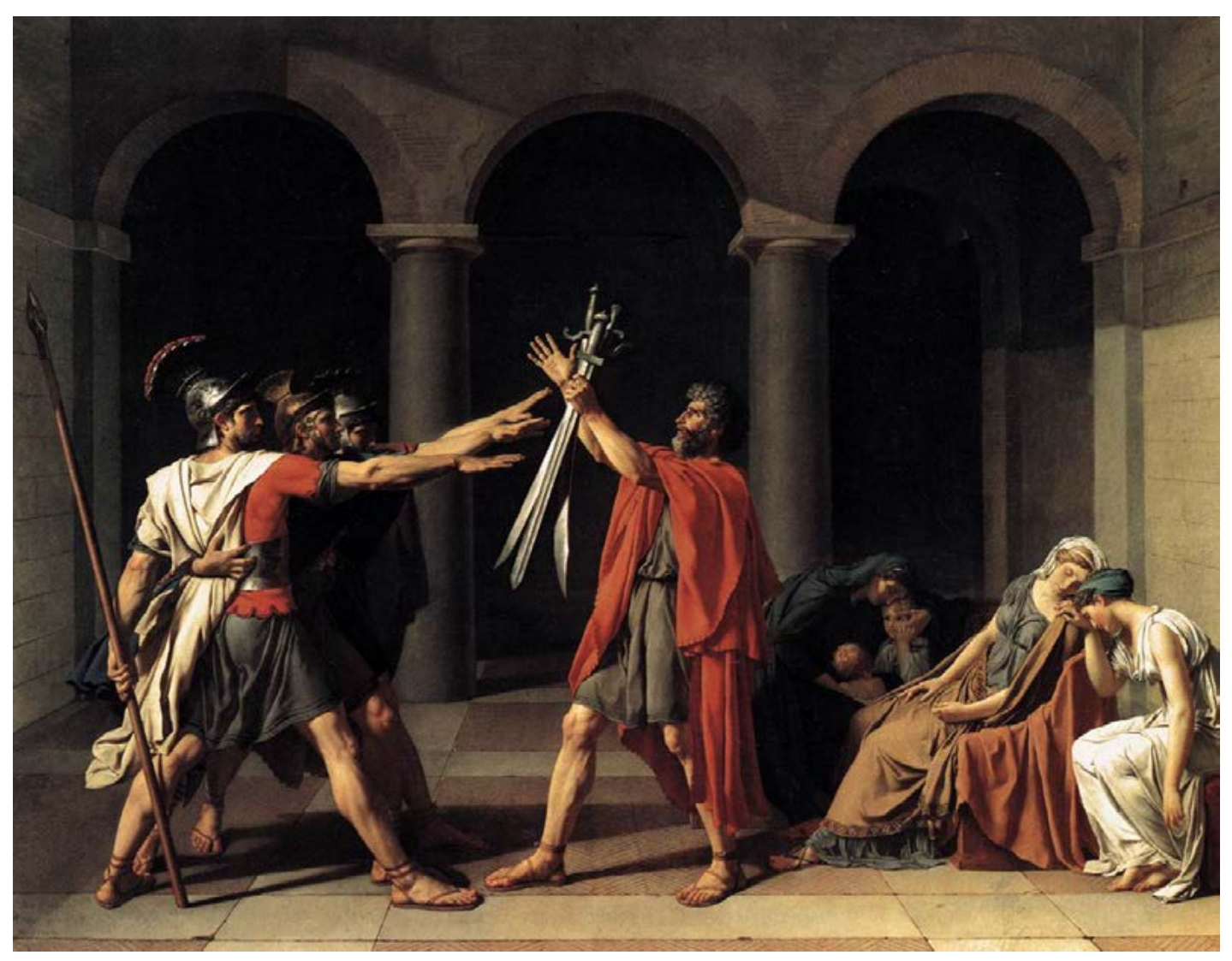

Oath of the Horatii, Jacques-Louis David (1784)

18 Fried vincula las dos modalidades temporales extremas de la representación, durativa e instantánea, con el carácter voluntario e involuntario (o «automatismo») de la acción, y el grado de conciencia de las figuras y objetos representados que la realizan: la modalidad instantánea y dramática correspondería a la acción consciente y voluntaria, y la durativa a una acción lenta y más o menos inconsciente o involuntaria. Habría una modalidad «intermedia» entre las dos anteriores. El autor sugiere que a lo absolutamente inanimado e inerte le correspondería, junto a la carencia de toda acción y conciencia, una ausencia total de tiempo. Cfr. el análisis que propone Fried (Menzel's realism, 193-194) de las poses y actitudes de tres personajes del gouache de Menzel titulado El Kronprinz Federico visita al pintor Pesne en su andamio en Rheinsberg (1861, Berlín, Nationalgalerie): el propio Pesne (voluntad), un violinista (automatismo, absorción) y un maniquí (inconciencia). 
Las modalidades pictóricas «absortiva-durativa» y «dramática» se insertan en la narrativa historiográfica de Fried sobre los orígenes del arte moderno, que sostiene la existencia de una «tradición antiteatral» francesa, premoderna, a la que habría precedido una «tradición absortiva barroca» ${ }^{19}$. La tradición antiteatral, surgida a mediados del siglo XVIII, respondería a una compleja problemática de «teatralidad»: la representación artística ha de evitar toda sensación de ser un artificio hecho para mostrarse y complacer al espectador; de lo contrario, no lo convencerá, sino que resultará «teatral»: parecerá que los personajes representados «posan» y se establecerá una distancia alienante entre espectador y representación, perdiendo ésta su credibilidad. Eso afecta también a los recursos expresivos y a la inteligibilidad de la obra pictórica: la obra expresivamente poco convincente, o cuyo tema o significado narrativo resulte ambiguo u oscuro, cae en lo «teatral $»^{20}$. Frente a ello, la tradición antiteatral habría mantenido el ideal normativo del tableau: la obra pictórica "completa» y autosuficiente, independiente del espectador y del contexto de su exhibición, que logra producir la «ficción suprema» de que el espectador no está ante ella como una entidad separada y que se le opone. El contenido concreto de esa norma irá cambiando durante la evolución de la tradición antiteatral, conforme varíe aquello que resulta capaz de satisfacer las exigencias antiteatrales. A ello responderá el empleo de recursos de las modalidades absortiva y dramática, y sus combinaciones, en el curso histórico de la tradición «antiteatral», pues las representaciones de duratividad y de instantaneidad tienden a ir respectivamente acompañadas, en el plano de la relación obra-espectador, de efectos de delicadeza o proximidad (modalidad durativa) y de agresividad y confrontación (modalidad instantánea), según el esquema de Fried ${ }^{21}$.

Desde esta perspectiva, el autor atribuye a Manet un papel de bisagra (Manet's modernism, 404-413), ya que sería la figura de clausura de la tradición antiteatral, a la par que fundacional para el impresionismo y para el arte «modernista» que lo seguiría. Manet habría constatado la incapacidad de los recursos de cualquier modalidad de representación pictórica para dar solución definitiva al problema de la teatralidad y cancelar la condición teatral enraizada en la propia constitución ontológica de la obra de arte (que

19 La exposición básica de estas ideas está en la monografía de Fried sobre arte francés del S. XVIII, $A b$ sorption and theatricality; Courbet's Realism y Manet's Modernism, donde desarrolla ese argumento, completando su llamada "trilogía de la tradición antiteatral francesa». A la «tradición absortiva barroca» precedente alude más explícitamente en sus estudios sobre Caravaggio o Menzel («Thoughts on Caravaggio»; Menzel's realism). Respecto a las categorías historiográficas de Fried, nos remitimos a la sección 3.3 de nuestro estudio sobre el autor (Díaz Soto, Michael Fried).

20 La tradición antiteatral habría surgido como «reacción anti-rococó», especialmente adversa a la práctica del gran fresco mural alegórico y decorativo, al modo de Boucher o Tiépolo, por su efecto de excesiva dilatación temporal de la experiencia. Para los teóricos «antiteatrales», en ese tipo de obras la vaguedad expresiva y las erráticas miradas de las figuras resultarían antiabsortivas, y la dispersión compositiva, junto al abstruso simbolismo del programa iconográfico, ralentizaría excesivamente la comprensión (Fried, Absorption and theatricality, 88-90, $211 \mathrm{n} .77)$.

21 Hay dos problemáticas particulares que coimplican la teatralidad y la modalidad temporal. Una afecta al género pictórico del retrato (Fried, Absorption and theatricality, 109-115, 138, 169), donde la única acción del modelo representado es «exhibirse» (término maldito en la tradición antiteatral) para ser retratado, y cuya modalidad temporal sería una total inmovilidad, distinta y opuesta al componente durativo típico del tableau. La otra afecta a la fotografía, que en sus inicios compartiría los problemas de pintura y retrato, debido a los prolongados tiempos de exposición y «pose» entonces necesarios, pero que llegaría a convertirse en la verdadera técnica automática de producción instantánea de representación (aunque sin los peculiares recursos que son exclusivos de la técnica manual de la pintura), superando así el horizonte de la teatralidad, pero quedando también entre paréntesis, provisionalmente, para el modernismo. 
en definitiva, es siempre un artefacto hecho para exhibirse ante un espectador ${ }^{22}$ ). Ello estaría vinculado al interés de Manet por producir efectos de instantaneidad:

En los cuadros más característicos de Manet de la década de 1860, por otro lado, el énfasis cae estrictamente sobre la instantaneidad como tal, aunque el modo como lo hace exactamente, es algo que varía de un cuadro a otro (y como veremos, en algunos de sus cuadros la instantaneidad coexiste con algo distinto, una quietud o detención que, sin embargo, no es absortiva) (Manet's modernism, 292-293).

Tal pretensión se consumaría en obras de Manet como el célebre Desayuno sobre la hierba (Le déjeuner sur l'herbe, 1863, París, Musée d'Orsay), mediante recursos plásticos como figuras fuertemente recortadas contra el fondo, como si estuvieran impresas sobre él, contrastes entre áreas de color poco matizadas, o la ambigüedad de la ubicación espacial; recursos que asimismo enturbian toda posible relación dramática entre las figuras ${ }^{23}$.

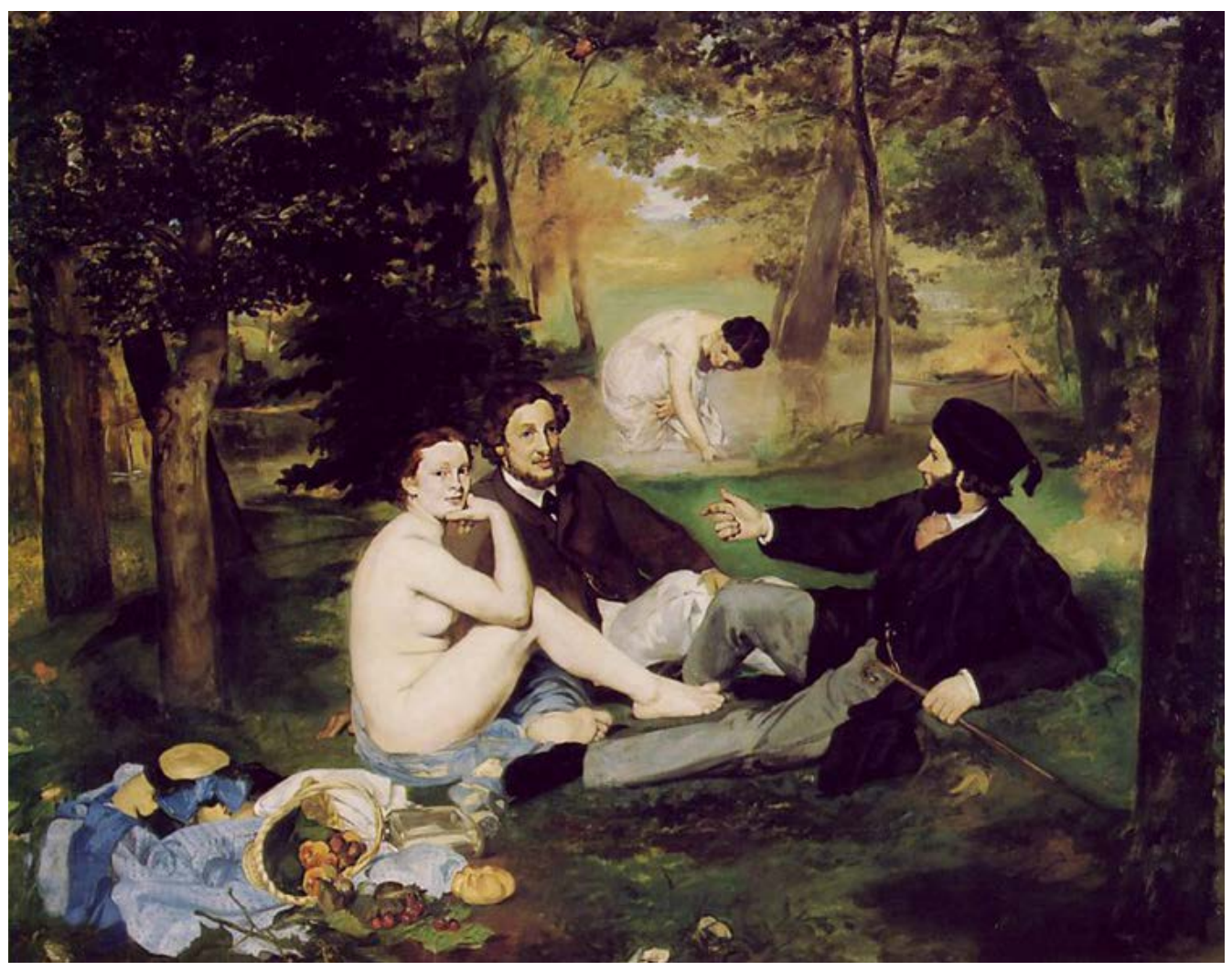

Le déjeuner sur l'herbe, Édouard Manet (1863)

22 Y lo sigue siendo, aun cuando esté concebida para ocultarse, y no exhibirse, al espectador (como sucederá con ciertas obras ya de época reciente): el espectador es un referente constitutivo de la condición óntica de la obra de arte.

23 Téngase en cuenta que, según Fried, la instantaneidad en Manet no es siempre del mismo tipo, ni se pone de relieve con los mismos temas iconográficos o recursos pictóricos. Sólo en ciertos cuadros suyos de la década de 1860, y cada vez más en sus obras posteriores (en parte por influjo de sus propios seguidores impresionistas), aparecería el decidido interés por la instantaneidad, digamos, «pura». 
De tal modo, Manet habría roto el delicado equilibrio entre aspectos absortivo-durativos y dramático-instantáneos que hizo posible el tableau antiteatral, para optar decididamente por la representación de la instantaneidad pura en sí misma, como tal ${ }^{24}$. Ello supone la supresión de todo cuanto conllevaba la poética «absortiva» del realismo tradicional, que se remontaba al Barroco, y que, según Fried, mostraba un mundo en penumbra, corpóreo y táctil, de volúmenes, espacio profundo y gradaciones de claroscuro: un mundo que tarda en recorrerse y cuya experiencia exige duración. Asimismo, Manet habría renunciado a la inteligibilidad narrativa y la coherencia expresiva en la representación de gesto y acción ${ }^{25}$ :

[...] la ocupación de Manet con efectos de instantaneidad señala un retorno a uno de los propósitos fundamentales de las composiciones dramáticas de David en la década de 1870. Pero, a excepción de un puñado de obras [...], su interés por la instantaneidad no le condujo a representar pictóricamente un momento de una acción, sino más bien a intentar evocar lo que llegó a entenderse como la instantaneidad de la visión, de la propia percepción visual (Manet's modernism, 296, cursivas en el original).

De modo que «[lo que] ocupó el lugar de la narrativa más amplia de la histoire en los cuadros de historia de David de la década de 1870 fue una narrativa implícita de la percepción, en la que el pintor pretendía representar una escena tal como se le aparecía en un golpe de vista» (Manet's modernism, 299, cursivas en el original).

Gracias a ello, Manet habría logrado emancipar la producción artística nueva de su dependencia respecto de la tradición de obras maestras del pasado (el «arte de los museos»), para lograr suscitar convicción. Un rasgo importante de la tradición artística occidental sería, según Fried, su «estructura de memoria» («Painting memories», 516, 518, 523): el espectador occidental vería en cada obra nueva las huellas o «resonancias» de otras obras maestras del pasado, identificando rasgos iconográficos y formales comunes entre aquélla y éstas, lo cual contribuiría a la valoración de las mejores obras de nueva creación, insertándolas en la tradición. Ahora bien, el origen de la modernidad artística, en que el autor ubica a Manet, sería una crisis de la precedente e «ingenua» relación, antaño positiva y productiva, de la época presente con la tradición y el pasado (que son la

24 Hasta cierto punto, Manet habría compartido esta preocupación con sus contemporáneos de la «Generación de 1863", según Fried. Agotada la eficacia de todas las estrategias antiteatrales anteriores, los críticos y artistas de entonces habrían creído que la instantaneidad, con sus efectos asociados de confrontación y agresión, era capaz todavía de suscitar la convicción propia del ideal del tableau. Pero sólo Manet habría llegado a desechar totalmente tanto los elementos absortivos como la propia exigencia antiteatral, para producir un peculiar tipo de convicción, que es casi una agresión al espectador: un «imprimirse» (to stamp in) y un «destacarse» (to stamp out) de aquello que se presenta ante la vista, todo a la vez, en la superficie delimitada del soporte pictórico (Fried, Manet's modernism, 294, 329-331).

25 En Manet, acompañaría a la renuncia a las estrategias antiteatrales una «resistencia a los modos disponibles de comprensión pictórica» (Fried, Manet's modernism, 22), y una incapacidad, tanto de sus contemporáneos (pertenecientes aún a la «tradición antiteatral») como de sus sucesores, para entender el proyecto pictórico de Manet de hacer disponible «la pintura en su totalidad». Proyecto que Fried sólo pretende haber logrado descifrar parcialmente, pues el caso de ese artista sería tan extremo que ni siquiera desde la posición hermenéutica retrospectiva del historiador resultaría completamente franqueable. Habría un "resto", o remanente no cancelable de ininteligibilidad, en el proyecto pictórico de Manet (Fried, Manet's modernism, 359, 401), aun cuando su frustrada voluntad habría sido hacerlo abiertamente comprensible (111). La cuestión de la temporalidad está, pues, ligada a cuestiones de significado e inteligibilidad de la obra pictórica. 
figura que a ese nivel toma tiempo y duración $)^{26}$. Crisis que, ya hacia mediados del siglo XIX, habría obligado a plantear abiertamente la naturaleza de la relación creación-tradición, a veces en forma de eclecticismo historicista y cita explícita, suscitando reacciones críticas frente a tal situación.

La respuesta de Manet habría consistido en afirmar ante el espectador la presencia real y física de la obra, con toda la literalidad de su medio (soporte, pigmento), explotando los efectos de fijación o "impresión», en sentido casi tipográfico, de los motivos representados del cuadro en la mente del espectador ${ }^{27}$. Tales recursos, luego malinterpretados por la recepción impresionista de Manet (Fried, Manet's modernism, 407-409), corresponden a una estrategia de "confrontación», que pone al descubierto la separación y distancia óntica entre obra y espectador (mutual facing), al ya mentado precio de abandonar la representación a su inevitable condición teatral y de renunciar a los valores de la absorción (inteligibilidad narrativa y expresiva, empatía con el espectador, etc.). Sólo así habría logrado Manet "poner a disposición» la totalidad de la tradición pictórica (painting altogether) para la posteridad $(167,175,408-409)$. Lo cual supondría también la definitiva «liquidación» de toda relación premoderna («segura»e ingenuamente productiva) con dicha tradición, para afirmar frente a ésta la actualidad del presente, de un modo que, dejando atrás viejas relaciones de dependencia basadas en la imitación, garantizaría al mismo tiempo, y paradójicamente, la continuidad de lo moderno con la tradición.

Como resultado de ello, formaría parte de la «eficacia histórica» de Manet el haber impuesto y alimentado una «mitología de la percepción visual» y del acto pictórico de representación como supuestos actos «instantáneos» y necesariamente correlativos (pues la instantaneidad de la visión iría de la mano con una análoga rapidez en la realización de la representación de dicho acto perceptivo), que habría seducido al subsiguiente impresionismo, caracterizado como representación de la «impresión instantánea» y de fugaces efectos «ópticos» de luz. La nueva mitología impresionista de la actividad pictórica convierte el complejo «rapidez de aprehensión-agilidad de ejecución» en objeto privilegiado de representación: al representar efímeros efectos lumínicos, en obras como Impresión, sol naciente de Monet (1872, París, Musée Marmottan), la pintura creería pintarse a sí misma, representar aquello en lo que ella misma consiste como actividad específica. Rapidez visual y agilidad técnica serán las virtuosísticas habilidades, visual y manual, exigidas ahora al pintor ideal; se construye así la imagen modélica de Manet como pintor

26 Esta era una de las tesis centrales de "Manet's sources» (Fried, Manet's modernism, 45), el texto de 1969 que el autor retoma e inserta, 25 años después, como capítulo inicial de su Manet's Modernism: tesis que ha de relacionarse con la noción de «situación modernista» que manejan Stanley Cavell y el propio Fried. En «Three American painters», Fried (Art and objecthood, 260-262 n. 4; cfr. Manet's modernism, 465467 n 65) sostuvo otra interpretación de Manet, en términos de representación de la alienación del sujeto en el mundo moderno, pero luego la abandonó, para insertar a este artista en su historia de la «tradición antiteatral».

27 La opción opuesta sería la de Baudelaire, en su Salón de 1846: radicalizar esta dependencia del pasado, instaurando el inefable «aura» mnemónico de la obra (la red de sus asociaciones con obras maestras memorables de épocas pasadas de la tradición) como el «medio» mismo de la pintura; con el riesgo de disolver las fronteras entre el presente y el pasado, confundidos en un borroso espacio mnemónico mental subjetivo, y de eclipsar la fisicidad y presencia visual de la obra ante la subjetividad imaginativa del espectador (Fried, «Painting memories», 515, 521, 531, 536-567 n. 22). Esa propuesta extirparía la raíz misma de la teatralidad, que es la separación/confrontación óntica entre obra y espectador. Pero además de impracticable, sería nefasta en último término para el arte, pues implicaría la disolución de los medios artísticos en la mera «interioridad» subjetiva. El propio Baudelaire, según Fried, se habría percatado, y reaccionaría contra ello en El pintor de la vida moderna. 
con dos atributos profesionales característicos: un ojo rápido y una mano tan ágil como su ojo (Fried, Manet's modernism, 301, 397). Ello habría dado pie a las teorías formalistas de la pintura (reduccionistas y simplificadoras) como el arte "puramente visual», que excluye tiempo y narración y que se desentiende del contenido representativo, y a la interpretación de todo el arte moderno en esos términos por teóricos del siglo XX como Roger Fry o Greenberg, la cual estaría ya anticipada en la equívoca recepción de Manet por los críticos del impresionismo $(415)^{28}$.

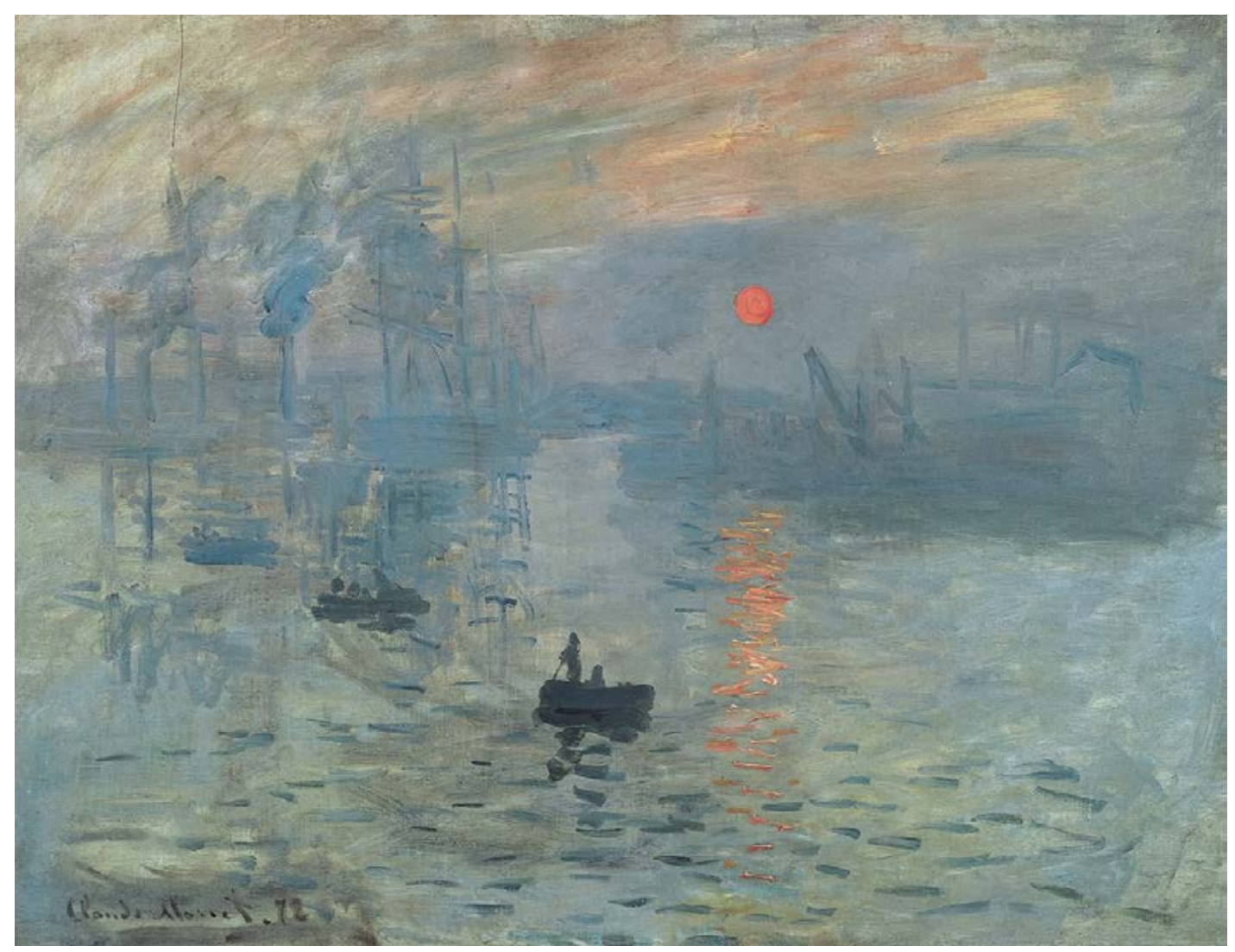

Impression soleil levant, Claude Monet (1872)

Ahora bien, hay dificultades en el planteamiento de Fried. Por un lado, el autor parece dar por sentada la viabilidad de la representación pictórica del tiempo «durativo», y en cambio, presenta la noción de una representación instantánea «pura» en artes plásticas, sobre todo en pintura figurativa, como irresolublemente aporética (Manet's modernism, 357), pues ni el acto visual ni el correspondiente acto pictórico en que se lo representa

28 El proyecto historiográfico de Fried, que presenta la historia de la tradición antiteatral francesa como prehistoria del arte moderno, se revela así como un verdadero «argumento genealógico» contra el «modernismo formalista» de Greenberg. Pero permítasenos expresar dudas respecto al vínculo entre ese contexto, tan específicamente moderno y francés, y los autores, germanos y de gusto conservador e italianófilo, que históricamente fundaron el formalismo. 
son «realmente» instantáneos ${ }^{29}$. Tal aporía de la representación pictórica de lo instantáneo se manifestaría en una tensión que atravesaría toda la obra de Manet: entre la rapidez o la velocidad del movimiento, vinculada a la instantaneidad, de una parte, y de otra, la quietud o inmovilidad (318-346). Esa tensión produciría efectos de «congelación», es decir, la representación o captación de la rapidez del movimiento de un cuerpo detenido en uno cualquiera de sus instantes, o bien la representación de un instante congelado de percepción dentro del proceso dinámico perceptual. Y se presentaría en el plano icónico de los contenidos representativos, en obras como el propio Desayuno sobre la Hierba (Manet's modernism, 319-321), como contraste entre figuras completamente estáticas y en actitud estable de reposo, y otras en posición y actitud inestable, o en movimiento (como sucede con el pájaro de la parte superior central del cuadro). Pero también se daría análoga tensión entre este plano icónico y el de los recursos plásticos, entre la posición o pose estática de ciertas figuras o motivos (es el caso de la rana, en la parte inferior izquierda del cuadro) y el empleo de una técnica «veloz», abocetada, para representarlos, produciendo un efecto de "disonancia cognitiva», al no corresponder ese tipo de ejecución al carácter estático del motivo. Otra alegoría de la contradicción entre instantaneidad e inmovilidad la ve Fried en las diversas versiones de La ejecución del Emperador Maximiliano, donde el acto de fusilamiento y el pelotón de ejecución representados parodiarían la instantánea y violenta rapidez de su propia «ejecución» abocetada (Manet's modernism, 356-357).

Pero por otro lado, conforme al planteamiento del propio Fried, tal instantaneidad de la representación pictórica tiene, cuando menos, una posibilidad, fundada en la planitud delimitada del soporte pictórico. Y dado el papel histórico central que el autor confiere a Manet, la instantaneidad del presente se erigiría, en cierto sentido, en modalidad temporal privilegiada de la pintura, al menos en la era modernista. Modalidad que en Fried, de forma parecida a lo que sucedía en el formalismo, permanece vinculada a cierto modo privilegiado de manifestación, o presentness, que sería característico del genuino arte «modernista» (tanto de la pintura como de la escultura):

Es como si la experiencia que uno tiene de [la pintura y escultura modernistas] no tuviera duración — no porque de hecho uno experimente una pintura de Noland u Olitski o una escultura de David Smith o [Anthony] Caro en ningún tiempo en absoluto, sino porque a cada momento la obra misma se manifiesta completamente. (Esto es verdadero para la escultura a pesar del hecho obvio de que, siendo tridimensional, puede ser vista desde un número infinito de puntos de vista. [...]) Es esta presentness continua y entera, equivalente, por así decir, a una perpetua creación de sí mismo, la que uno experimenta como una especie de instantaneidad, como si, siendo uno infinitamente más agudo, un instante infinitamente breve pudiera ser lo bastante largo como para verlo todo, para experimentar la obra en toda su profundidad y plenitud, para quedar convencido por ella (Art and objecthood, 167).

29 Así argumenta Fried: un verdadero acto visual «instantáneo» debería ser absolutamente instantáneo; y su adecuada representación pictórica requeriría un acto manual de ejecución igualmente instantáneo, para dar al motivo representado su modalidad temporal apropiada (el autor piensa aquí en una plástica "pictoricista», suelta y abocetada). Pero tan imposible sería un acto absolutamente instantáneo de aprehensión visual (ya que la percepción es un proceso, un continuum durativo) como el acto pictórico totalmente instantáneo de ejecución manual necesario para representarlo con justicia: sólo un medio automático o mecánico de representación (la fotografía, por ejemplo) podría hacer tal cosa. 
Ahora bien, la presentness de Fried no es la at-onceness del «formalista» Greenberg: no es el mero darse «todo-a-la-vez», instantáneo, de los contenidos plástico-formales de una composición "decorativamente» satisfactoria, sino un acceso pleno e inmediato al contenido expresivo y al significado profundo de la obra. Tampoco apela a las nociones formalistas de «esfera sensorial» y "pura visualidad», ni a una separación de las artes basada en adscribirlas unívocamente a "esferas sensibles» ${ }^{30}$.

Presentness designa un acto delimitado, cerrado y completo de donación de significado, que se produciría en la experiencia del arte modernista. En él, la obra lograda ha de manifestar plenamente, una y otra vez, la idea central (the point) que le da sentido según la intención del artista modernista, la apuesta personal de éste en respuesta a un problema artístico, impuesto por su propia comprensión de la situación histórica actual del medio artístico con el que trabaja. Lo que se da en semejante experiencia, pues, trasciende la duración, en el sentido de que es algo bien definido, que se da totalmente y se nota que se ha dado por completo, pero ha de darse plena y totalmente de nuevo a cada instante. Y ello, con independencia de que el encuentro obra-espectador tenga una duración que se prolongue literalmente en el tiempo o implique un desplazamiento de punto de vista en el espacio; y sin excluir que entre los contenidos transmitidos en dicha experiencia estén cualidades de modalidad temporal durativa, exploración lenta del espacio profundo, tactilidad, etc.

Es así como la obra modernista debe suscitar convicción, y lograr renovarla «a cada instante». Pero, ¿̇sería eso incongruente con el reconocimiento de la pertinencia pictórica de los valores del tiempo y la duración? No, pues aquí no se trata simplemente de una supuesta validez exclusiva de la «instantaneidad», sino del «acto de gracia» de la transmisión del significado artístico y la convicción (Fried, "How Modernism works», 78 n. 17; Art and objecthood, 44-45, 167). Un «una-y-otra-vez», en el cual el instante se presenta mediado con la duración, de una peculiar manera ${ }^{31}$ :

Mi idea [en "Art and objecthood»], diría yo hoy, era que a cada momento la pretensión de la pintura o escultura modernista sobre el espectador se renueva totalmente; como si nada menos que eso fuera la condición de su expresividad. Por ello mismo, la convicción del espectador en la seriedad de la obra, su «calidad», no está fuera de duda siquiera por un momento, o lo está sólo por un momento (un estado de cosas modernista con creces): la convicción - la gracia- debe asegurarse una y otra vez, como continuamente, por la obra misma, pero también, en el acto de experimentarla, por el espectador, por nosotros (Fried, Art and objecthood, 47).

Análogamente, por así decirlo, a la realización de lo trascendente en la inmanencia, este acto puede volver a acontecer, o dejar de hacerlo, a cada instante del continuo de la duración: no tiene garantía de logro definitivo. Y por ello cada instante tiene la misma importancia: en todos ellos se juega por igual lo trascendente; o en términos laicos, en todos ellos se juega la calidad de la obra, la plenitud de su sentido, la legitimidad de su propósito artístico, la autenticidad del compromiso ético de su autor con la tradición cultural de la cual es deudor.

30 Fried no abandona el «principio de separación de las artes» (que el formalismo defendió), y afirma que la calidad y el valor artístico sólo son posibles en el marco de medios artísticos particulares (Art and objecthood, 43, 85). Pero en su teoría de los medios artísticos rechaza todo esencialismo, y su formulación del citado principio pretende desligarse de cualquier presunto fundamento formalista en una división de «esferas sensoriales» o en una esencia "puramente óptica» de la pintura.

31 Con ecos de la lectura de Kierkegaard que propone Stanley Cavell (163-79). 
No obstante, la noción de presentness ha venido interpretándose en términos de «purovisualismo» formalista, del «todo-a-la-vez» greenberguiano, conforme al cual lo instantáneo, cuando no la lisa y llana atemporalidad, sería la condición propia de lo "puramente visual», y por ello, del arte plástico. Siguiendo la interpretación propuesta por «antigreenberguianos» de la talla de Rosalind E. Krauss (Passages, 173-204; The optical unconscious, 1-27) y otros, se ha criticado el vínculo establecido por Fried entre la inteligibilidad, la instantaneidad y la noción valorativa de "convicción", bajo el cargo de ser una reformulación, idealista y con resabios teológicos, de la autonomía del arte como trascendencia de las condiciones reales (temporales, materiales) de la experiencia del mismo ${ }^{32}$. Y los detractores de Fried han relacionado su crítica a las neovanguardias de los años 60 con la polaridad formalista entre opticidad-planimetría-instantaneidad y tactilidad-volumetría-sucesividad, y con la exaltación de la primera serie de términos y la aversión hacia la segunda.

El joven Fried, en su muy discutido artículo «Art and objecthood», de 1967, polemizó contra el minimalismo y otras corrientes de neovanguardia, que él denominó «literalistas», y las condenó por «reduccionistas» (al «objetualizar» la obra artística, reduciéndola a los más crasos elementos «literales» de su soporte físico ${ }^{33}$ ) y por «teatrales» (al explotar fáciles recursos sensacionalistas para hacerse con el interés del espectador, a costa de la pérdida de credibilidad de las obras $\left.{ }^{34}\right)$. El autor criticaba allí el énfasis puesto por artistas «literalistas», como Robert Morris, Tony Smith, Carl André o Donald Judd, en la duración temporal literal de la experiencia y los efectos de "presencia» material de sus «obrasobjeto", cuya estructura formal se reducía a la reiteración seriada de un único módulo, de prosecución potencialmente infinita, o bien a una Gestalt cerrada y totalmente simple (cubo, paralelepípedo, etc.):

La interminabilidad, la posibilidad de seguir y seguir, incluso la necesidad de seguir y seguir, es central tanto al concepto de interés como al de objetualidad. De hecho, parece ser la experiencia que excita más profundamente la sensibilidad literalista, y que los artistas literalistas buscan objetivar en su obra - por ejemplo, por la repetición de unidades distintas (el «una cosa tras otra» de [Donald] Judd), que tiene la implicación de que las unidades en cuestión podrían multiplicarse hasta el infinito.

[...] la experiencia en cuestión persiste en el tiempo, y la presentación de la interminabilidad que, según he venido sosteniendo, es central para la teoría y el arte literalista, es una presentación de la duración sin fin o indefinida [...] La preocupación literalista por el tiempo - más exactamente, por la duración de la experiencia - es, como quisiera sugerir, paradigmáticamente teatral, como si el teatro hiciera frente al espectador, y por tanto, lo aislara, con la interminabilidad, no sólo de la objetualidad, sino del tiempo; o como si el sentido al que el teatro se dirige fuera, en el fondo, un sentido de la temporalidad, tanto del tiempo que pasa como del que está viniendo, simultáneamente aproximándose y alejándose, como si se aprehendiera desde una perspectiva infinita [...] (Art and objecthood, 166-167; cursivas en el original).

32 De este tenor son también las objeciones de T. J. Clark a Fried (86-87, 88 n. 7). Fried niega enérgicamente que su crítica contra la duratividad literalista obedezca a la formulación habitual de la autonomía del arte como escisión entre arte y vida; por el contrario, subraya el vínculo del arte con el mundo y lo cotidiano u «ordinario», que es el contexto de una reivindicación de la temporalidad extensiva por parte de Fried.

33 Reduccionismo del que Fried acusa también a Greenberg, y con él al formalismo (Manet's modernism, 168-169 n. 6).

34 Según ello, el problema de la teatralidad habría vuelto a cobrar centralidad para el arte modernista, un siglo después de la clausura de la «tradición antiteatral» por Manet. 
La decisión del espectador de poner fin a la experiencia de la obra literalista que lo mantiene atrapado (como la de poner fin a la obra abierta de estructura iterativa, por parte del artista «literalista») sólo puede ser un acto arbitrario y unilateral por su parte de arrancarse a ella. A esos aspectos, que serían centrales para el literalismo, Fried opuso su noción de presentness como ideal normativo del auténtico arte «modernista».

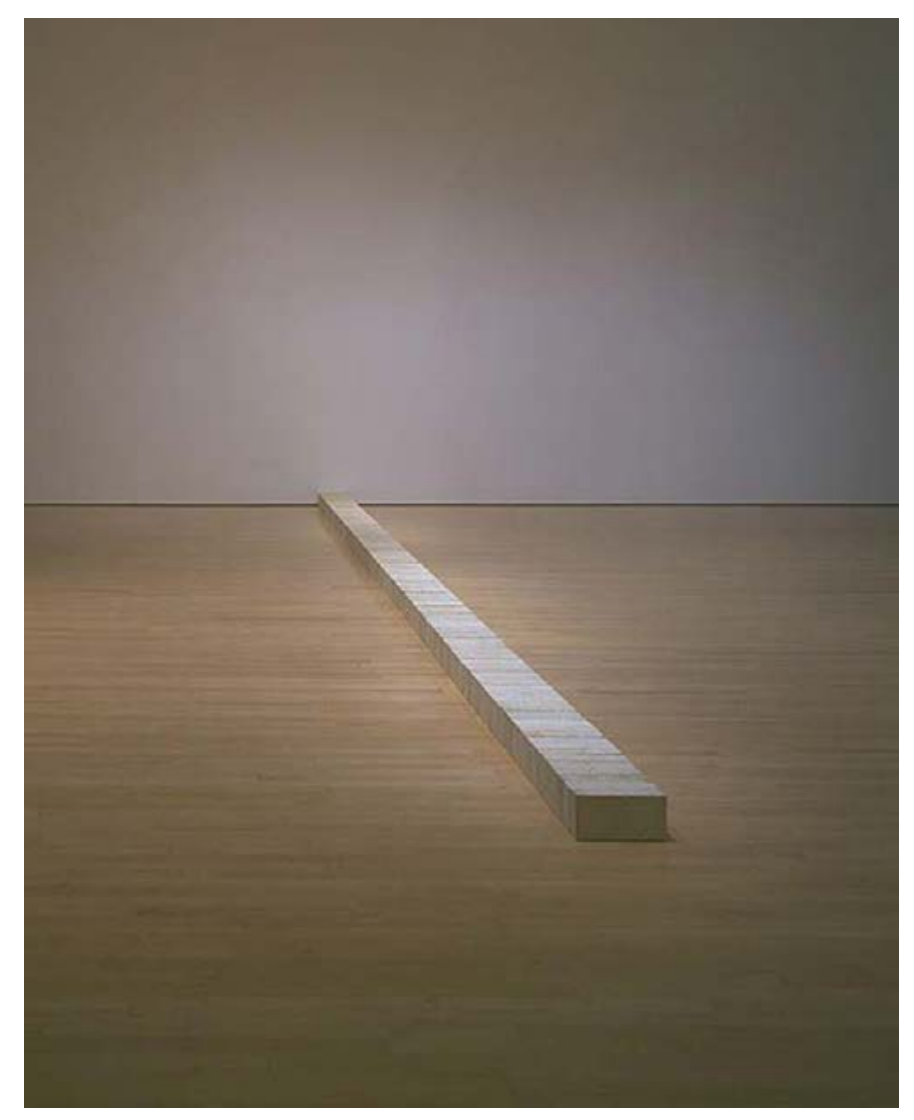

Lever, Carl André (1966)

En realidad, según explicó años más tarde, lo que él desaprobaba en el literalismo no era simplemente su afirmación de la presencia de la obra (cosa que también hizo, legítimamente, un modernista como $\mathrm{Manet}^{35}$ ), sino su mera fisicidad inerte, ónticamente opaca y opuesta a la plenitud de sentido de la presentness. Y tampoco censuró, meramente, que empleara «efectos de tiempo»; el problema para él no radica en la duración en sí misma, sino en algo que el literalismo hace con ella para poder teatralizarla, y que a su parecer la corrompe. El literalismo enfatiza la duración real, literal y mensurable, del en-

35 Entre afirmación de la presencia literal de la obra por Manet, primer artista modernista, y por los literalistas, lo que media es un matiz de intención: en Manet, reconocer la insalvable condición teatral de la obra artística y sanear la relación con la tradición; en los literalistas, explotar la fisicidad para obtener fáciles efectos de fascinación en el espectador, reduciendo la obra a un mero objeto arbitrario. Ello supone, para Fried, todo un abismo de diferencia de calidad y legitimidad entre la obra de aquél y la de éstos. 
cuentro entre obra y espectador, ligada a una sospechosa indefinición del significado de la obra, para «escenificar» la temporalidad como mera duración literal, bajo el aspecto específico de la infinitud, o interminabilidad, teñida de una desesperante vacuidad vital, y de emociones más bien negativas, entre la atonía y la angustia, tales como «expectación, temor, ansiedad, presentimiento, memoria, nostalgia, estasis» (Art and objecthood, 171 n. 22): cualquier cosa menos serenidad, entrega al presente, aceptación afirmativa de la finitud, bienestar o alegría de vivir.

Aquí está en juego algo que rebasa el orden «estético»: una distinción entre dos concepciones o valencias vitales, «buena» y «mala», de la duración y de la cotidianidad, o de lo "ordinario", como lo denomina el filósofo Stanley Cavell, interlocutor cercano de Fried, inspirándose en Wittgenstein, Kierkegaard y el romanticismo norteamericano de Emerson, Whitman o Thoreau. Cavell describió en términos de presentness la relación del hombre con el mundo no contaminada por el escepticismo (318-326). En ella, al hombre se le da plenamente su mundo; eso le exige la máxima acuidad de su atención a cada instante y la máxima responsabilidad sobre su acción (acompañada, empero, de una modalidad temporal durativa y direccional, intencionalmente orientada). Pero la tentación que el escepticismo poscartesiano supone para el sujeto moderno ejercería sobre él un efecto distanciador, pasivizante, "teatralizante»; la tragedia del moderno sujeto escéptico sería la "pérdida del mundo", de su mundo cotidiano, que ha de volverse a ganar.

Las obras literalistas (o, en una versión figurativa del mismo asunto, las de ciertos creadores del entorno surrealista, como De Chirico), sugiere Fried, serían expresión de una ideología que manifiesta el lado oscuro de la Modernidad, con su «mala» concepción de la infinitud del tiempo como totalidad isócrona y agregativa de células de duración indiferenciadas; totalidad que se extendería indiferente e indefinidamente en cualquiera de sus dos direcciones, pasado y futuro (Menzel's realism, 283-284 n. 14). Es así como el hastiado hombre moderno padece la duración de su vida cotidiana, sus condiciones materiales de existencia. En la modalidad negativa de lo ordinario, la vida en la tierra parece absurda y sin sentido, sus tareas no son asumidas sino impuestas, realizadas desganada y rutinariamente, y el paso repetitivo del tiempo interminable es el aburrimiento y la falta de sentido, de los que hay que escapar, sin que el hombre pueda encontrar cómo. Igual que al espectador de la obra literalista siempre le queda la alternativa de arrancarse a tan desdichada situación, en el acto llamado «suicidio».

Habría, en cambio, otra cara «positiva» del tiempo durativo de la cotidianidad: un modo afirmativo de vivirlo, como duración direccional del tiempo, cargada de acción y articulada por un propósito vital. Fried, debatiendo contra la concepción pesimista de la Modernidad de su colega y rival T. J. Clark (Menzel's realism, 231-239), pretende hallar su representación en ciertas obras de Menzel, que muestran albañiles absortos en su tarea, en un solar en construcción ${ }^{36}$ :

Lo que quisiera subrayar, sin embargo, son las implicaciones temporales, es decir, estéticas, del motivo de poner ladrillos [en obras de Menzel]: me refiero al modo como un albañil pone, uno tras otro (uno junto a otro) un gran número de ladillos, todos los cuales son casi exactamente idénticos, en hileras que son ellas mismas casi exactamente idénticas y que de hecho están puestas unas sobre otras, en un proceso repetitivo que en principio no tiene término necesario. Veo en esto una analogía con el modo en el cual, en cuestiones

36 El propio Fried reconoce el parecido entre esta descripción y el proceder del artista literalista. De nuevo, la diferencia decisiva es de matiz. 
de intrahistoria, «cada pequeño momento es de la mayor importancia» y por tanto no ha de ser menospreciado; en la albañilería, asimismo, no se trata de «aferrarse al momento intensivo", de hecho no hay nada tal como un momento intensivo; la esencia de la tarea, en su forma "pura», consiste precisamente en su entrega a la extensividad temporal (153).

En el modo positivo de lo ordinario, el hombre, como ser finito que ha aceptado su condición de tal, logra hallar su lugar en la vida en esta tierra, en la repetición perpetua de una tarea siempre inacabada, de resultado siempre provisional (sin momentos «intensivos", que alcancen logros heroicos de conquista definitiva), pero plenamente asumida en un acto de absorción, que crea el lazo del hombre con su mundo. Absorto y entregado a sus tareas cotidianas más insignificantes (uneventful), en un mundo en el cual se encuentra bien y que reconoce como el suyo, el hombre siente satisfacción con su existencia mundana y el paso del tiempo durativo le resulta tan leve como para pasarle desapercibido.

La neovanguardia literalista, según Fried, es nihilista: sus obras representan el paso vacío del tiempo isócrono, que corre sin sentido. Sería, pues, lo opuesto mismo a la modalidad absortivo-durativa de los pintores antiteatrales premodernos, como Chardin, que representaron la duración, sí, pero llena de sentido: "Imágenes como éstas [refiriéndose, entre otras obras de Chardin, a Pompas de jabón, 1733, Washington D.C., National Gallery], no lo son del tiempo desperdiciado, sino de un tiempo lleno (como un vaso podría estar lleno no sólo hasta el nivel de su borde, sino ligeramente por encima)» (Absorption and theatricality, 51). Pero, como advierte fugazmente (Absorption and theatricality, 61, 200 n. 120), ellas eran ya entonces, en el momento de tránsito hacia la modernidad artística (y hacia la sociedad moderna en sentido fuerte), representaciones de un mundo del pasado: de un modo de vida dado y asegurado por la tradición, que lo llena de pequeños rituales cotidianos donadores de sentido. Un modo de vida que ya se estaba perdiendo ${ }^{37}$, arrollado por el torbellino del mundo moderno y de lo que Fried, con Cavell, denomina «situación modernista» (Cavell, xxii, 116, 207-208, 219-220; Fried, Art and objecthood, 235-236), cuyo único rasgo permanente y seguro es la incertidumbre. Arrojado a ella, el hombre moderno tiene la tarea, siempre inacabada, de recobrar constantemente la posesión (la presencia) de su cotidianidad en su aspecto positivo, lleno de sentido; pero también corre siempre el riesgo de sucumbir a la negatividad de una existencia vacía y sin sentido. Y su éxito en esa tarea no le está asegurado de antemano, ya que en los "desencantados» tiempos modernos, donde la tradición ya no es garantía de nada, nada asegura que lo ordinario no se malogre (Fried, Menzel's realism, 157, 165, 174).

Si el tiempo de lo cotidiano es durativo e insignificante, en la modernidad se torna, además, inmanente y desencantado. Igualmente lo es el «tiempo de la modernidad artística» indicado en la noción de presentness de Fried, pues, al contrario que en época premoderna, los procedimientos y normas heredados del arte tradicional ya no ofrecen certidumbre. Un tiempo en el cual el instante se encuentra mediado con la duración (y no aislado, ni contrapuesto a ella). Pues en ésta irrumpen instantes de gracia en que se logra la calidad y la convicción, se da totalmente el sentido de la obra y el espectador se entrega

37 Se trata de la pérdida de la vivencia «natural» y «absorta» de lo cotidiano que, según Cavell (322-324, 348), marcaría el tránsito del mundo premoderno a la modernidad plena, y a la cual aludíamos en nuestra nota 26. Nos remitimos a nuestro breve examen de la teoría cavelliana de la modernidad cultural (Díaz Soto, « Stasis», saturación cultural...», 31-34). 
plenamente a su experiencia. Pero un instante de plenitud no asegura nada para el futuro, y al instante siguiente la misma obra puede perder la convicción del espectador y ha de ser capaz de recobrarla constantemente. Tampoco un único instante resuelve la tarea del artista modernista, del crítico y del espectador modernos. No hay logros artísticos que puedan darse por definitivos, sino que, a cada sucesivo instante, todo es susceptible de crítica; todo está siempre por descubrir y plantea una tarea siempre pendiente. Porque la modernidad no es un tiempo de certezas, sino de incertidumbre y crisis.

\section{REFERENCIAS}

Cavell, Stanley. Must we mean what we say?: A book of essays. Cambridge: Cambridge University Press, 1995. Medio impreso.

Clark, T. J. «Arguments about Modernism: A reply to Michael Fried». Pollock and After: the critical debate. Ed. Francis Frascina. Chicago and London: University of Chicago Press, 1983. 81-88. Medio impreso.

Crary, Jonathan. Techniques of the Observer: On Vision and Modernity in the Nineteenth Century. Cambridge, Mass.: MIT Press, 1992. Medio impreso.

Díaz Soto, David. "Stasis», saturación cultural, pérdida de presencia». Bajo palabra. Revista de filosofía 3 (2008). 25-34. Medio impreso.

- - . Michael Fried y el debate sobre el formalismo norteamericano. Madrid: Publicaciones de la Universidad Complutense, 2010. E-prints Complutense. Sitio web. Fecha de ingreso: 20 de agosto de 2010.

Fiedler, Konrad. Escritos Sobre Arte. Ed. Francisca Pérez Carreño. Trad. Vicente Romano. Madrid: Visor, 1990. Medio impreso.

_-_. Schriften Zur Kunst. Ed. Gottfried Boehm. München: Fink, 1991. Medio impreso.

Fried, Michael. «Some notes on Morris Louis». Arts Magazine 37 (November 1963). 22-27. Medio impreso.

- _ - "Painting memories: on the containment of the past in Baudelaire and Manet». Critical Inquiry 10:3 (March 1984). 510-542. Medio impreso.

- - - «How Modernism works: A response to T. J. Clark». Pollock and After: the critical debate. Ed. Francis Frascina. London; Hagerstown, MD.: Harper \& Row, 1985. 65-79. Medio impreso.

- - Realism, writing, disfiguration: on Thomas Eakins and Stephen Crane. Chicago: University of Chicago Press, 1987. Medio impreso.

- - . Absorption and theatricality: painting and beholder in the age of Diderot. $2^{\circ}$ ed. Chicago: University of Chicago Press, 1988. Medio impreso.

- - C Courbet's realism. Chicago: University of Chicago Press, 1992. Medio impreso.

- - - «David et l'Antithéâtralite». David contre David. Ed. Régis Michel. París: La Documentation Française, 1993. I:199-227. Medio impreso.

- - - Manet's modernism, or, The face of painting in the 1860s. Chicago: Univ. of Chicago Press, 1996. Medio impreso.

_—_. «Thoughts on Caravaggio». Critical Inquiry 24:1 (Autumn 1997). 13-56. Medio impreso. 
. Art and objecthood: Essays and reviews. Chicago: University of Chicago Press, 1998. Medio impreso.

- - Menzel's realism: Art and embodiment in nineteenth-century Berlin. New Haven: Yale University Press, 2002. Medio impreso.

Greenberg, Clement. Clement Greenberg: the collected essays and criticism. Ed. John O’Brian. Chicago, Ill.; London: The University of Chicago Press, 1988-1993. Medio impreso.

Hanslick, Eduard. Vom Musikalisch-Schönen: ein Beitrag zur Revision der Ästhetik der Tonkunst. Wiesbaden: Breitkopf \& Härtel, 1971 . Medio impreso.

Helmholtz, Hermann von. Die Lehre von den Tonempfindungen als physiologische Grundlage für die Theorie der Musik. Braunschweig: Vieweg, 1863. Medio impreso.

-_- Handbuch der physiologischen Optik. Hamburg: Leopold Voss, 1909. Medio impreso.

Hildebrand, Adolf von. El problema de la forma en la obra de arte. Ed. Francisca Pérez Carreño. Trad. María Isabel Peña Aguado. Madrid: Visor, 1989. Medio impreso.

Krauss, Rosalind. Passages in modern sculpture. Cambridge Mass.: MIT Press, 1981. Medio impreso.

-_- The optical unconscious. Cambridge Mass.: MIT Press, 1994. Medio impreso. Lessing, Gotthold Ephraim. Laocoonte. Trad. Eustaquio Barjau. Madrid: Tecnos, 1990. Medio impreso.

Müller, Johannes. Handbuch der Physiologie des Menschen für Vorlesungen. Koblenz: Hölscher, 1834. Medio impreso.

Wölfflin, Heinrich. Kunstgeschichtliche Grundbegriffe: das Problem der Stilentwicklung in der neueren Kunst. Basel: Schwabe, 2004. Medio impreso.

Recepción: 26 de mayo de 2011

Aceptación: 30 de junio de 2011 